\title{
The Application of the Traditional Consciousness of Scholar Painting in the Teaching of Chinese Painting in Art Colleges
}

\author{
Wenxiu Li \\ School of Art and Design \\ Huanghe Science and Technology College \\ Zhengzhou, China, 450063 \\ e-mail: 554287746@qq.com
}

\begin{abstract}
By analyzing the present condition of the teaching of Chinese painting in the art colleges, the author proposes the concept of introducing the consciousness of scholar painting into the teaching of Chinese painting. Through the detailed generalization of the concept of the consciousness of scholar painting, this paper finds the meaning of its application in the teaching of Chinese painting, and proposes specific proposals on how to use the traditional consciousness of scholar painting in the teaching of Chinese painting in art colleges.
\end{abstract}

Keywords-the consciousness of scholar painting; art colleges; the teaching of Chinese painting

\section{ARt COLleges StUdents MAJORING IN CHINESE PAINTING LACK THE PROFOUND TRADITIONAL ARTISTIC APPRECIATION}

\section{A. Outdated Teaching Methods}

At present, in the teaching of Chinese painting in art colleges in China, it is found that phenomenon like the lacking of basic skills, narrow scope of knowledge, poor cognition of Chinese painting, lacking of enthusiasm to the traditional culture, and low confidence in the traditional culture are the common situation of the students. The major reason of the present condition is that the teaching system of China is exam-oriented education. As a result, many art colleges take the aesthetics standards of sketch and color of western painting in examination when they enroll the students of Chinese painting, and require less of students' mastery on the special painting language of Chinese painting. Therefore, the students of Chinese painting major know little of the formal language of Chinese painting in the college. The basics of Chinese painting, pen and ink, is immersed into the teaching mode of western painting. Since the students rarely use writing brush, when learning the basic course of Chinese painting, they may confronted with a sudden change from the training of the western sketch modeling ability to the training of Chinese ink painting modeling ability. The sudden change in the thinking concept causes the strange sense and fear of difficulties of students toward the pen and ink language of Chinese painting. They accept the learning of Chinese painting passively, have scanty knowledge of the special Chinese painting language and barely know about traditional culture.

Chinese painting is the traditional painting of Chinese nation, deeply influenced by the thinking of Confucianism, Taoism, and Buddhism, and rooted in the profound cultural soil of Chinese nation. During its development of thousands of years, painters in different dynasties have explored continuously, formed a whole system integrating the special aesthetic consciousness, aesthetic ideology, artistic appreciation, way of thinking and philosophical concept of Chinese nation together. However, in the present teaching of Chinese painting in art colleges lacks the cultivation of comprehensive qualities of traditional culture, and takes not enough emphasis on the cultural characteristics of Chinese painting. Missing of humanistic connotation in teaching, emphasizing the training and mastering of traditional form and technique language in the teaching content and style cause the superficiality and shallow in the painting.

\section{B. Imperfection of the Enrollment Policy}

Since the continuous increase of university enrollment from the middle 1990s, the art colleges lowered the requirements on cultural quality in enrollment. The students not only have low academic ability, but also bad cultural ability. Mr. Liu Dawei, chairman of Chinese Artists Association, once said, "Rapid increasing enrollment scale, gradually identical school running model and over-emphasis on techniques but neglect creation are the common failings in the teaching of art education of higher learning. Many art colleges multiplied the scale of enrollment, causing the change of art education into "sheep herding" extensive style of teaching. Consequently, there will be many problems, such as weak faculty and insufficient teaching hardware of the colleges, low enrollment requirement of the students that they can pass the entrance examination through the short and fast training of art classes, stereotyped content of the academic examination, excessive emphasis on academic scores and low score on general knowledge course, and the students cannot meet the needs of the market after graduation, and so on." 


\section{Cultural Shock of Foreign Arts}

After the reform and opening-up, influenced by the foreign culture, abstract and ideational ink came into being. The value orientation of the students changed, being shortsighted and craving instant success and benefit. Because they lack the patience on the learning of traditional culture, they underestimate their own abilities on traditional painting, and blindly imitate the experimental ink painting that lacks cultural foundation. Therefore, the paintings blindly pursue craziness, strangeness, and visual impact, reducing the impressionistic manner of the artistic image of Chinese painting, and making the form of painting deviated from the traditional cultural more and more, losing the spirits of traditional culture. Therefore, it is imperative to propose the traditional consciousness of scholar painting in Chinese painting teaching in art colleges, open the subjects of traditional culture for students in a planned way and on purpose, and conduct effective experiment and reform on the teaching contents and methods.

\section{INTRODUCING THE CONSCIOUSNESS OF SCHOLAR PAINTING INTO ChINESE PAINTING TEACHING OF ART COLLEGES}

\section{A. About Scholar Painting and the Consciousness of Scholar Painting}

The consciousness of scholar painting originated from the painting concepts of Wang Wei in Tang Dynasty. Its rising was indispensible with the thinking of Shu in the middle and later periods of Northern Song Dynasty and the scholars group of Yuanyou period. Leading by Su Dongpo, a series of opinions on painting of the painters of the scholars group in the Yuanyou period demonstrated clear consciousness of scholar painting. They were influenced by the Taoism concept of advocating natural, proposed that painting should not be too strict on the similarity in form or appearance but to demonstrate the meaning and spirit naturally, and advocated the basic concept and the game of pen and ink in painting, against the practices of emphasizing the set pattern and the appearance but not the meaning in the imperial-court decorative painting. The academic viewpoint of emphasizing the symbolic meaning of the painting creation caused the overall thriving of the consciousness of scholar painting in the Northern Song Dynasty, set the ideology foundation for the development of scholar painting, and promote the development of Chinese painting from the single imperial-court decorative painting to the scholar painting that integrating poem, book, painting and seal together gradually. Since the Northern Song Dynasty, most scholar bureaucrats have advocated the concept of "conveying spirit through form and unity of form and spirit", emphasizing the spirit and ignoring the form, did not pursue the skill of depict and color. Therefore, they have achieved the artistic characteristics of "Art comes from life, but also need an artist's inspiration", opposing the "similar in form but strange in meaning" of the imperial-court decorative painting. These concepts have received unprecedented development during the Yuan Dynasty, influenced the development of painting in Ming and Qing Dynasty. The scholar bureaucrats have various styles of painting, however, no matter how the form changed, they all took great emphasis on cultural cultivation, pen and ink language and moral character. These three basic features of the scholar painting are the artistic core of Chinese painting, and also the important content of the artistic spirits of Chinese nation. In the nowadays with rapid development of science, technology and art, we cannot value the students by the learning and moral standards of the scholar painters in the past because the times are different. However, the traditional spirits of national art and the scholar painters' concept on emphasizing knowledge and self virtual still have great influence on the class teaching of Chinese painting in nowadays art colleges.

\section{B. The Meaning of Introducing the Consciousness of Scholar Painting into Chinese Painting Teaching of Art Colleges}

Chinese painting teaching in art colleges not only cultivate qualified talented framer of Chinese painting, but also innovation talents in the inheriting of the traditional culture, which is not simple inheriting of the techniques. Thus, it is particularly important to learn the spirits of traditional culture and the special modeling language of Chinese ink painting.

The scholar painter's ways of emphasizing on meaning, expressing feeling through things to represent the thinking of the scholar have deep meaning to the teaching of Chinese painting in art colleges. For example, plum, orchid, bamboo, and chrysanthemum are only common plants, however, under the painting of the scholar painter, the plum blossom in cold and snow means remain aloof from the world, the elegant fragrance of orchid represents preserve one's moral integrity, the hollow but vigorous of bamboo represents a sharp sense of integrity, and the blossoming of chrysanthemum in frost represents one's independence. This is rooted in the yearning of the ideal aesthetic personality from the painters and took them as the objects to compare with. Only after the students understand the deep meaning can they find the coherence point with the scholar painting. This has deep meaning to the learning and absorbing of the techniques of expression of traditional scholar painting.

Aesthetic consciousness and aesthetic taste cultivated by the nurturing of traditional culture dominated the scholar painters' ways of composition and the application of pen and ink in painting. The beauty of a painting can only be understood from the poetic charm, but not the similarity of appearance. In the teaching of Chinese painting in art colleges, if the students are only be required from techniques and appreciation, they may be driven to a dead end, which resulted superficial and shallow creation of Chinese painting of the students in the future.

At present, the academic education has broken the traditional mentoring teaching mode. The education mode has formed its own scale and system. It is necessary to emphasize the important meaning of the spirits of traditional scholar painting in the teaching of Chinese painting in the whole process of Chinese painting teaching, because it contains the essence of traditional Chinese culture and it is 
the base of learning Chinese painting. Only after one learned the profound traditional culture, achieved a mastery through the comprehensive study of the spirits of Chinese nation can he deeply understand the form of the special painting, and better learn and innovate the Chinese painting.

\section{THE APPLICATION OF THE TRADITIONAL}

\section{CONSCIOUSNESS OF SCHOLAR PAINTING IN THE TEACHING} OF CHINESE PAINTING IN ART COLLEGES

The spiritual consciousness and aesthetic standards of the scholar painting maintained the inheriting and development of traditional Chinese painting, existed and lasted for thousands of years. The thought has very deep influences, and still has important meaning in guiding the Chinese painting teaching in modern art colleges. Therefore, it is necessary to introduce the traditional consciousness of scholar painting into the teaching of Chinese painting in art colleges. In the specific application of the traditional consciousness of scholar painting in Chinese painting teaching, following strategies should be abide by.

\section{A. Construct Correct Consciousness Orientation, Improve the Thinking and Creative Abilities of the Students}

In response to the problem that students majoring in Chinese painting in art colleges have low cultural qualities, teachers should guide them to set up right artistic view in consciousness first. The scholar painting emphasized that "poem as drawing", which required good comprehending ability and solid Chinese traditional cultural quality of the one learned painting. It was a painting with strong spirits. In ancient times, a scholar painter should first be a scholar, learned and knowledgeable, and then became an official, or focused on study in secluded mountains and cottages. To them, painting was only few pens of drawing when they were in high spirits, with not in a least of utility thought. Literary poems, calligraphy and seal cutting are the best skills they must have to settle down and get on with their pursuit. It is because the scholar painter has such profound cultural qualities that their paintings have deep humanistic connotation. The teaching of Chinese painting in modern art colleges should learn from the spiritual consciousness of scholar painting, trace back to the origin of traditional culture, emphasize the internal education, and break the old teaching system aimed at the improving of painting skills thoroughly. Or else, learning Chinese painting is like water without a source, and a tree without roots.

\section{B. Cultivate the Noble Characteristics of the Students; Comprehend the Relationship between Personal Character and Painting Character}

In the viewpoint of scholar painters, personal character was the first of painting, which even controlled the application of painting techniques. Guo Ruoxu in Song Dynasty once mentioned in "Tu-Hua Jian-Wen Zhi, on Artistic Conception is not the Mentor", one with fine moral quality should have fine artistic conception; one with fine artistic conception should paint vividly; and thus he is skillful at painting. This showed the important relationship between personal character and artistic conception and vividness in painting. The scholar painter believed that the moral quality determines the feelings a painting aims to display. It was known that one with bad character has no rule when drawing, while one with high moral qualities could draw even when he is play. From this, it can be found that the cultivation of moral quality and the noble character are the spiritual requirements of learn Chinese painting. College students should build a whole character, cultivate noble sentiment and without distractions can they learn Chinese painting well.

\section{Change the Traditional Teaching Mode, Planning Subjects, Add the Education of Traditional Culture, and Improve the Cultural Quality of Students.}

Without the nurturing of traditional culture, Chinese painting would be shallow and superficial. Mr. Lu Yanshao has learned painting for 60 years to become a painting master. He summarized the efforts of learning painting: $40 \%$ on reading, $30 \%$ in writing and $30 \%$ on painting. The teaching of Chinese painting in art colleges should be aimed at the improvement of students' humanistic and scientific qualities. When making the teaching plan, there should be traditional culture subjects like classical literature, traditional art, ancient philosophy, and history, etc. and ensure enough teaching hours, cultivating students' interests into the learning of traditional culture. In the class of Chinese painting, the teacher should not only emphasize the illustration and explanation of theory, but also blend the traditional painting theories and the related comprehensive art into the teaching process, theory combining with practice, constructing a scientific and humanistic teaching framework that is suitable for the development of Chinese painting teaching, comply with the developing trend of Chinese painting, and making the reform of Chinese painting teaching be kept in the category of traditional scholar painting aesthetics. In the spare time, the teacher should list some theoretical books and paintings related to the teaching of Chinese painting for the students to learn, further widening their scope and improving their understanding and aesthetic ability toward Chinese painting.

\section{Learning and Absorbing the Nutrients of Other Artistic Classes, Earnestly Carry out the Training Techniques of the Basic Skills}

As the visual perception art, Chinese painting is inseparable from technologies. To strengthen the technical training on the basis of cultivating aesthetic connotation is essential in the teaching of Chinese painting. In ancient times, scholars took special attention to the draw calligraphy into painting, thus the important function of calligraphy should be emphasized in the teaching of Chinese painting. Calligraphy and seal cutting should be established as a compulsory course. Mr. Lu Yanshao once said, “One doesn't need to draw each day, but the practice of calligraphy should not be interrupted." No matter in the class or out of the class, the students should learn calligraphy persistently. Calligraphy and painting have the same roots. In history, many famous calligraphers are painters as well, like Huang Tingjian, Su Shi, Mi Fu, and Zhao Mengfu, etc.. Zhao Mengfu once wrote 
a poem at the end of his "Painting of Elegant Stone and Open Forest": "painting stone should use Feibai (a style of calligraphy characterized by hollow strokes) and wood the Zhou (a style of script or calligraphy), while paint bamboo should employ the eight principles of Yong. If one knows the relationship between painting and calligraphy, he should know that calligraphy and painting have the same roots." This poem emphasized the importance of calligraphy in painting. Therefore, in the class teaching, the teacher should combine the common point of calligraphy and painting, and analyze the characteristics of calligraphy, making the students know well the rules of using brush in Li script (an ancient style of calligraphy current in the Han Dynasty) and running script, and other styles of calligraphy and techniques of writing, and the running of lines and ink in Chinese painting. Combine the training of calligraphy and painting organically, the teacher should not only teach the students to master the basic techniques in the class, but also require them to practice calligraphy after class, finish on time and check regularly, effectively promote the improvement of the techniques of Chinese painting. Because the traditional calligraphy is not the only writing way now, the students should renew their understanding toward calligraphy and train hard in order to understand the beauty of the fact that calligraphy of painting have the same roots.

Another content that cannot be ignored in the teaching of Chinese painting in art colleges is seal cutting. Seal cutting is small, but combines calligraphy, drawing and the beauty of knife techniques together, in between of calligraphy and painting. When teaching the knowledge of seal cutting, the teacher should analyze the distribution of red and white colors with the composition and the layout of a painting, master the training of carving skills with the structure and technique of writing, making the students be familiar with the form and features of seals in different dynasties, the developing headstream and features of carving skills of different schools. A seal with fine content, profound message and natural carving skill contains deep cultural connotation. The teacher should lead the students to pay special attention to the function of a seal in the painting, which not only enlighten the drawing, balancing the whole painting, but also add the aesthetic appeal. In addition, in the teaching of Chinese painting, the teacher also needs to purposely lead the students to dabble in the arts like Chinese Peking opera, and classical music, etc., especially to understand the charm and aura of Peking opera by heart, and master the lively spirit and charm, the artistic conception and the style of Chinese painting. The comprehensive study and mastery of different kinds of arts will effectively promote the training of the basic skills of Chinese painting.

\section{CONCLUSION}

Applying the above four requirements into the teaching of Chinese painting in art colleges, the students should learn from the traditional scholar painting consciousness, accept the nurturing of traditional Chinese culture actively, study deeply, correctly master the relationships among different painting elements like theme, form, technique and connotation, etc., and know well of the key of traditional painting. Only in this way can the students improve their drawing skills in Chinese painting, and better learn and inherit Chinese culture. The teaching of Chinese painting in art colleges will be on its right way.

\section{REFERENCES}

[1] Chen Chuanxi. History of Chinese Landscape Painting [M] . Suzhou: Jiangsu Fine Art Press, 1988.

[2] Chen Hengke. The Value of Humanistic Painting [M]// Shao Qi, Sun Haiyan. Discussion Papers on Chinese painting in the 20th Century. Shanghai: Shanghai Literature \& Art Publishing House, 2008.

[3] Fu Baoshi. Fu Baoshi Art Essays [M] . Suzhou: Jiangsu Literature and Arts Publishing House, 1986. 